\title{
Address by the President of the Institute and Faculty of Actuaries Ms Marjorie Ngwenya
}

[Institute and Faculty of Actuaries, 28 June 2017]

Contact: presidents@actuaries.org.uk

The President (Ms M. C. Ngwenya, F.I.A.): Ladies and gentlemen, respected members of the profession, family and friends. Welcome to you and all our guests this evening.

I am humbled and honoured to be standing in front of you as your new President.

I am honoured to be taking on the challenge of leading the Institute and Faculty of Actuaries at such a time of change.

So how did I arrive at this position?

Indeed, why did I become an actuary?

I was raised in a small city called Gweru in Zimbabwe. My parents were the first generation of degreeeducated people in their family. For them education was everything. As a high school graduate, my range of career options was clear and limited. I was going to follow a profession. It was not negotiable.

I wanted to be intellectually stimulated and rewarded in my work. Ideally, my career would also allow me to explore the world.

So, when I discovered that actuarial studies had posed an elusive feat to all but a few of my peers in Zimbabwe and, liking a challenge, it appealed to me and gave me the drive to succeed. And so I did.

I started my actuarial studies at the London School of Economics in London. But very early on at university, the Zimbabwe dollar began to depreciate, making it really tough for my parents to keep me in London.

Therefore, I decided to withdraw from my studies and I took a job as a tax associate at Deloitte.

When an actuarial vacancy arose in the company, I applied for the job, and got it, conditional on passing the actuarial exams.

I do not have an undergraduate degree but, despite that, I went on to qualify as an actuary while working.

But I also acquired a taste for volunteering. After many actuaries had given up their time to help me qualify, I decided that editing the UK profession's magazine was the least I could do in return. I spent 3 years as editor of The Actuary magazine. 
I also volunteered for examination marking, teaching and eventually serving on the Institute and Faculty of Actuaries (IFoA)'s Council. This will be my 7th year on Council.

I am grateful to my parents for their insistence on a robust education and I am thankful to Council for their support and faith in nominating me to my new role.

Given I do not resemble those who came before me, I was both surprised and delighted to have been nominated to become the first non-UK-based President of the IFoA.

I am the third female President of the UK profession in 159 years and one of seven Council members based abroad.

Nearly $50 \%$ of our members are based overseas. Our profession is increasingly diverse. We have come a long way.

It is a time of change. Change brings about challenges, opportunities and risks. As actuaries, understanding risk is our business.

During my year as your President, I wish to ensure that not only do we continue to help people to understand risks, and the role of actuaries in this regard, but that we also help them to make the most of the opportunities that arise with change.

The world is changing fast - as are the economies in which we live and work.

The skills and values that actuaries can bring are more relevant and needed than ever before.

There is a push-back against the effects of globalisation. Mass migration - both of refugees and economic migrants - is putting a strain on national borders.

As a result, the ideals of openness and free movement are under threat. The walls are going up, limiting the free movement of people, ideas and knowledge. It all stifles the spirit of openness that generates and sustains the growth of the world, its economy and indeed humanity.

With new technologies such as artificial intelligence, robotisation and autonomous machines, we are on the brink of the fourth industrial revolution. The impact of this revolution, some say, will make many of the unskilled, lower paid workforce, redundant. We can already glimpse it, as we self-check-out at supermarkets, as autonomous cars and trucks are tested on our roads, and as Amazon tests its delivery drones.

Artificial intelligence also seeks to process some of the complex issues that actuaries have traditionally solved. Even actuaries may see themselves as under threat.

But let us look at what changes may come. Let us see what we can learn from history and gaze into the future.

Some predict that the price of energy will cease to be a limiting factor.

Virtual reality will become the new reality, so we can experience things in the virtual world before we try them in the real world. 
With the extinction of many species, perhaps the virtual world will offer what once was the real world - for those that can afford it.

We are approaching the age of the "always-on" workers, many of whom will be freelance as their location becomes less important than their availability.

We will not have employees anymore as talented, skilled workers will not want to be owned, but will instead sell their services more openly into the market.

We will live significantly longer and many of us will follow more than one career.

Our healthcare will be dramatically different as diagnostics will be quicker, more accurate and automated. The highly qualified doctors of today will find their work of diagnosing, treating and providing care changes significantly. The impact of technology will move the emphasis of their work to where human intervention is necessary - the actual care of the patient. Your local GP will still be needed but they will have to adapt and evolve into their new role.

Likewise, actuaries face the challenge of changing their focus to one that is less concerned with the analysis of data, but more focussed on the insights to be gained from that data.

We will be adding value from the visualisation of that data, and advising on meaningful interventions and solutions based on those insights.

Actuaries understand connectivity and our role will be to communicate meaning and impact of the risks and the trends that we identify.

Let us think about some of the man-made technologies that have introduced large changes.

- In 1817, a German inventor rode the forerunner of the bicycle in Mannheim.

- In 1831, the first steam train ran in the state of New York.

- The first remote control was created in 1950 and the first microwave oven followed about 5 years later.

- The first polaroid camera was sold in 1948 and the first brick-sized phone was introduced by Motorola in 1984.

- The internet was first commissioned in the 1960s by the US government for military communication and introduced to the public in the mid-1990s.

And looking at the average age of the audience here, I'm sure we all recall the era of cassette tapes, VHS recorders, phone boxes, fax machines, camera film and floppy disks.

As I was researching our origins, I was overwhelmed by the richness of our history as a profession and fascinated in particular by the development of the insurance industry.

I learned that the Great Fire of London in 1666 gave rise to the formation of fire insurance companies.

The profession, as we know it today, dates back to as early as the $17^{\text {th }}$ century when the mathematics of longevity and compound interest were being scientifically explored.

As a profession, 200 years ago we were creating life tables on a piece of paper. 
As technology advanced, we moved from pencils and paper to punch cards and from slide rules to communal computers.

We began to rely on computers to do the number-crunching and to tackle much more complex modelling.

Actuaries developed techniques to make the calculations as easy as possible - calculations to manage the financial loss of events beyond our control.

Who can say what comes next? From today's personal computers to tomorrow's personalised robots?

What is certainly true is that we are a profession that is capable of adapting.

Whilst today we increasingly act as advisors, in tomorrow's world the computational elements of our training will be automated by artificial intelligence.

As actuaries we will translate the outcomes into meaningful guidance for real world businesses and public sector challenges.

Our key skills will be to simplify complexity, to communicate the ideas and to forge relationships based upon them and, of course, uphold high standards.

Together, that will differentiate us and give our role value and meaning in a world where for many work will seem increasingly meaningless.

If the actuary of yesteryear was primarily a mathematician, the actuary of today is primarily a communicator of the outcomes of the mathematical puzzles that we face.

The actuary of tomorrow will be a highly skilled and valued consultant, guiding clients and societies through the complex challenges that they will be facing.

We will be acting to protect and enhance the environment and sustainable prosperity of the communities in which we live.

So, in my year as your President, what will I be doing to help actuaries prepare for our changing role, and to seize the opportunities that will doubtless arise?

For a start, I will be continuing the journey begun by my predecessors.

First, I will be ensuring that we are future-fit, by which I mean being clear about the value that we can add to businesses and society, and communicating that effectively.

I am reminded of a Zimbabwean proverb that states that, "Until the lion has his own storyteller, the hunter will always have the better part of the story".

Our ability to communicate the value of our skillset is vital. 
Second, I will be continuing to broaden the areas in which we work, translating our skills to benefit new industries.

Lastly, I believe that we need to be collaborating - both more and more effectively - within and beyond our profession.

We are a relatively small profession of around 60,000 actuaries globally relative to a couple of million accountants. To realise our ambitions, we must partner with others.

So what does this mean for the IFoA? It means raising our sights to widen our appeal across the world.

To reflect that our membership and audience are increasingly global, we must promote an accessible and relevant education framework that will be attractive and useful to societies and those in them that wish to professionalise their skills.

As the leading professional body for actuaries, we need to ensure that our regulation of the profession stays relevant as the changes introduced by the fourth industrial revolution take effect.

We must not stifle our members or their innovation. We must ensure that our professional standards continually develop so that our people are respected, trusted and valued as we enter new markets and areas of work. From where I stand, it is vital that we maintain an open and global perspective.

We must continue to be the professional body of choice in a world where our prospective members will be faced with so many options.

My vision, for us as a profession, is to broaden our sphere of influence; to ensure that we are heard on relevant matters; going beyond being heard solely in financial services to provide valuable input and insights into a wide range of industries and public sectors.

Our skills give us a natural edge in this regard - an ability to understand the interaction of complex changes.

In my view, it is a great time to be an actuary and a great time to demonstrate the wide applicability of our skillset.

In my mind, we will have been successful if we are responsible custodians of actuarial science and continue to provide a valuable service to the public in navigating the risks that come with change.

So, as your President, I pledge that I will serve you and the best interests of our IFoA. I am keen to hear from you and to understand how our combined efforts can best serve the profession.

Unlike a better known President, I shall not tweet. I shall not spread false news and I shall not build walls and get others to pay for them.

Instead, I look forward to working with Council, the executive team and volunteers, keeping us focussed on being forward-looking, inclusive and proactive in broadening our influence for the betterment of our societies. 
I thank you all for your commitment, your drive and the innovation that you are demonstrating as we embrace this world of change.

To Council - thank you for your support. It has been a pleasure to work with Fiona [Morrison] as immediate past president, Colin [Wilson] as outgoing president and a very warm welcome to Jules [Constantinou] as president elect.

To my valued family and friends, many of whom have travelled from afar, and to my unwavering parents, thank you for your encouragement, and of course, thank you all for being here to share this moment with me. 